\title{
Plasmodium falciparum proteome changes in response to doxycycline treatment
}

\author{
Sébastien Briolant 1,2, Lionel Almeras 1,2, Maya Belghazi³ ${ }^{3}$ Elodie Boucomont-Chapeaublanc ${ }^{1}$, Nathalie Wurtz ${ }^{4}$ \\ Albin Fontaine1,2, Samuel Granjeaud5, Thierry Fusaï1,2, Christophe Rogier1,2 and Bruno Pradines*1,2
}

\begin{abstract}
Background: The emergence of Plasmodium falciparum resistance to most anti-malarial compounds has highlighted the urgency to develop new drugs and to clarify the mechanisms of anti-malarial drugs currently used. Among them, doxycycline is used alone for malaria chemoprophylaxis or in combination with quinine or artemisinin derivatives for malaria treatment. The molecular mechanisms of doxycycline action in P. falciparum have not yet been clearly defined, particularly at the protein level.

Methods: A proteomic approach was used to analyse protein expression changes in the schizont stage of the malarial parasite P. falciparum following doxycycline treatment. A comparison of protein expression between treated and untreated protein samples was performed using two complementary proteomic approaches: two-dimensional fluorescence difference gel electrophoresis (2D-DIGE) and isobaric tagging reagents for relative and absolute quantification (iTRAQ).

Results: After doxycycline treatment, 32 and 40 P. falciparum proteins were found to have significantly deregulated expression levels by 2D-DIGE and iTRAQ methods, respectively. Although some of these proteins have been already described as being deregulated by other drug treatments, numerous changes in protein levels seem to be specific to doxycycline treatment, which could perturb apicoplast metabolism. Quantitative reverse transcription polymerase chain reaction (RT-PCR) was performed to confirm this hypothesis.

Conclusions: In this study, a specific response to doxycycline treatment was distinguished and seems to involve mitochondrion and apicoplast organelles. These data provide a starting point for the elucidation of drug targets and the discovery of mechanisms of resistance to anti-malarial compounds.
\end{abstract}

\section{Background}

The parasitic protozoon Plasmodium falciparum is responsible for approximately 247 million cases of malaria and one million deaths each year, particularly in sub-Saharan Africa [1]. Anti-mosquito measures and new artemisinin-containing treatments have been recently adopted in hopes of achieving the global eradication of malaria. Novel drugs, vaccines and insecticides, as well as deeper insights into parasite biology, human immunity, and vector behaviour, are essential to support these efforts [2].

\footnotetext{
* Correspondence: bruno.pradines@free.fr

1 Unité de Recherche en Biologie et Epidémiologie Parasitaires, Institut de Recherche Biomédicale des Armées, Antenne de Marseille, BP 60109, 13262 Marseille Cedex 07, France

Full list of author information is available at the end of the article
}

Over the past 30 years, experimental observations obtained in vitro and in clinical studies have demonstrated the anti-malarial activity of tetracycline and its derivatives [3]. Daily doxycycline (DOX) has been shown to be an effective chemoprophylactic in Thailand [4], Indonesia [5], and Kenya [6]. DOX is currently one of the recommended chemoprophylactic regimens for travellers visiting malaria endemic areas in Southeast Asia, Africa and South America [7]. DOX is now recommended by the French Consensus Conference for chemoprophylaxis in countries with a high prevalence of $P$. falciparum resistance to chloroquine or multiple drugs [8]. However, while no instances of $P$. falciparum malaria clinical failure with DOX have been reported yet, three different phenotypes (low, medium and high DOX susceptibility groups) have been identified among $P$. falciparum clinical isolates 
[9]. These different phenotypes have been associated with pfmdt and pftetQ copy number variations and pftetQ sequence polymorphisms [10].

DOX has long been known to inhibit protein synthesis in bacteria [11] by binding the S4, S7, S9 and S17 proteins of the small $30 \mathrm{~S}$ ribosomal subunit and various ribonucleic acids of the 16S rRNA, which prevents the binding of aminoacyl transfer RNA to site A of the ribosome [12]. In $P$. falciparum, tetracyclines have been reported to directly inhibit mitochondrial protein synthesis [13] and also to decrease dihydroorotate dehydrogenase activity, which is involved in de novo pyrimidine synthesis [14]. DOX inhibits $P$. falciparum synthesis of nucleotides and deoxynucleotides [15]. Minocycline, another tetracycline derivative, also decreases the transcription of mitochondrial genes and plastid genes, indicating that it may target these two organelles [16]. More recently, two research groups $[17,18]$ reported specific action by cyclines on the apicoplast of $P$. falciparum via cell biology and transcriptome approaches. Collectively, these published data indicate that organelles from $P$. falciparum seem to be primary targets for cyclines; however, the molecular mechanisms involved in this plastid regulation are not yet clearly defined, particularly at the protein level.

Proteome studies have contributed substantially to our understanding of parasite biology and host-parasite interactions [19]. Mass spectrometry (MS) methods have been used to enable large-scale identification of proteins at different stages of the malarial parasite life cycle $[20,21]$. However, few proteomic analyses have been undertaken to better understand the mechanisms of drug action or resistance in $P$. falciparum. The effects of chloroquine and artemisinin derivatives on $P$. falciparum have been studied using different proteomic techniques, such as a gel-based approach [22], SELDI (Surface Enhanced Laser Desorption Ionization) TOF (Time of Flight) MS analysis [23] and, more recently, isoleucine-based SIL (Stable Isotope Labelling) [24]. Until now, P. falciparum proteome response following doxycycline treatment has not been studied.

The present study aimed to highlight the metabolic pathways that are affected in P. falciparum following DOX treatment. To accomplish this objective, two complementary proteomics approaches were used: twodimensional fluorescence difference gel electrophoresis (2D-DIGE) and isobaric tagging reagents for relative and absolute quantification (iTRAQ). The combination of these two technologies allowed us to identify proteins that are deregulated in response to doxycycline and were involved in various cellular functions such as redox homeostasis, stress response, protein synthesis, lipid synthesis and energy metabolism. These results indicated that $P$. falciparum organelles seem perturbed by DOX treatment, suggesting that these are the drug's primary targets.

\section{Methods}

\section{Plasmodium falciparum growth conditions and protein extraction}

Parasites (chloroquine-resistant W2 clone) were maintained in continuous culture as described elsewhere [25], at $10 \%$ haematocrit of type $\mathrm{A}^{+}$human RBCs suspended in supplemented RPMI 1640 (Invitrogen) and 10\% heatinactivated type $\mathrm{A}^{+}$human serum at $37^{\circ} \mathrm{C}$ in a gas mixture of $5 \% \mathrm{CO}_{2}, 10 \% \mathrm{O}_{2}$ and $85 \% \mathrm{~N}_{2}$. The medium was changed twice daily. Parasitaemia was monitored daily via microscope by examination of blood smears stained with a RAL 555 kit (Réactifs RAL). Parasite synchronization was performed by sorbitol treatment (D-sorbitol, ICN Biomedicals) as described elsewhere [26]. At the ring stage, parasites were or were not exposed to DOX (Sigma) at $10 \mu \mathrm{M}$ (the $\mathrm{IC}_{50}$ as previously determined [27]) for a period of $24 \mathrm{~h}$. Parasites at the schizont stages during the second cycle after DOX exposure were extracted from the RBCs. Control and treated groups consisted of four biological replicates for the DIGE experiment and three biological replicates for the iTRAQ experiment. IRBCs were washed 3 times in PBS (Invitrogen) and lysed by $0.1 \%$ saponin (Sigma) for $5 \mathrm{~min}$. Free parasites were sedimented by centrifugation $(9,300 \mathrm{~g}$ for $5 \mathrm{~min})$ and washed with PBS 3 times and stored at $-80^{\circ} \mathrm{C}$. Parasites were resuspended in $10 \mathrm{mM}$ Tris- $\mathrm{HCl}$ buffer $(\mathrm{pH} 8)$ and disrupted by ultrasonication (Vibracell 72412, Bioblock Scientific) for $5 \mathrm{~min}$ on ice at maximum amplitude. After ultracentrifugation $\left(100,000 \mathrm{~g}\right.$ for $1 \mathrm{~h}$ at $\left.4^{\circ} \mathrm{C}\right)$, soluble protein fractions were recovered from the supernatant and the pellet containing membrane protein fractions was then suspended in 4\% (w/v) 3-[(3-cholamidopropyl)dimethylamonio]-1-propanesulfonate (CHAPS) (Sigma). All of the fractions were precipitated in $100 \%$ acetone (Sigma) to remove lipids, and the protein concentration of each sample was estimated using the Lowry-based DC assay (Biorad) according to the manufacturer's instructions. All of the samples were suspended in standard cell lysis buffer (7 M urea, $2 \mathrm{M}$ thiourea, $4 \%$ CHAPS, $30 \mathrm{mM}$ Tris base, pH 8.5 (Sigma)) to obtain a protein concentration adjusted to $2.5 \mu \mathrm{g} / \mu \mathrm{L}$.

\section{D-DIGE}

Protein samples were minimally labelled with CyDye according to the manufacturer's recommended protocols (GE Healthcare). Briefly, soluble protein samples from the control parasites $(50 \mu \mathrm{g})$ and the DOX-treated parasites $(50 \mu \mathrm{g})$ were labelled with $400 \mathrm{pmol}$ of either Cy3 or Cy5 (in four biological quadruplicates, with a dye swap) and an internal standard $(50 \mu \mathrm{g})$ was labelled with 400 pmol of Cy2, freshly dissolved in N, N-dimethylforma- 
mide (DMF) (Sigma), and incubated on ice for $30 \mathrm{~min}$ in the dark. The reaction was quenched with $1 \mu \mathrm{L}$ of free lysine $(10 \mathrm{nM})$ by incubation for $10 \mathrm{~min}$ on ice. Cy3-, Cy5- and Cy2-labeled samples were then pooled, and an equal volume of $2 \times$ sample buffer was added ( $8 \mathrm{M}$ urea, 2 M thiourea, 4\% (w/v) CHAPS, $10 \mathrm{mM}$ dithiothreitol (DTT), and $1 \%(\mathrm{v} / \mathrm{v})$ immobilized pH gradient (IPG) Buffer 3-10 (GE Healthcare). The membrane protein samples were treated as described above with either IPG Buffer 47 or IPG Buffer 6-11 (GE Healthcare). The mixture of labelled proteins was then separated by two-dimensional gel electrophoresis (2-DE) (See additional file 1 for more details).

\section{2-D Image analysis}

Gel images were acquired with a Typhoon Trio Image scanner (GE Healthcare) at different excitation wavelengths (Cy3, 580 BP 30/green (532 nm); Cy5, 670 BP 30/ red (633 nm); Cy2, $520 \mathrm{BP} 40 /$ blue $(488 \mathrm{~nm})$ ). Images were cropped with ImageQuant software (GE Healthcare) and further analysed using DeCyder v6.5 (GE Healthcare). The software was used to perform gel alignment, spot averaging and normalization and Student's $t$ test to determine which protein spots changed in abundance in response to DOX-treatment. The number of detected spots showing a difference with a $p$-value of $<$ 0.05 was then determined.

\section{In-gel trypsin digestion}

After imaging, the gels were stained either with Sypro Ruby (Bio-Rad) according to the manufacturer's protocol and then scanned using the typhoon scanner or with Coomassie Brilliant Blue (CBB) G-250 as previously described [28]. Spots of interest were manually excised. Protein spots were digested overnight at $37^{\circ} \mathrm{C}$ with sequencing-grade trypsin $(12.5 \mu \mathrm{g} / \mathrm{mL}$; Promega Madison) in $50 \mathrm{mM} \mathrm{NH}_{4} \mathrm{HCO}_{3}$ (Sigma). The resulting peptides were extracted with $25 \mathrm{mM} \mathrm{NH}_{4} \mathrm{HCO}_{3}$ for 15 min, dehydrated with acetonitrile (ACN) (Sigma), incubated with 5\% formic acid (Sigma) for 15 min under agitation, dehydrated with $\mathrm{ACN}$, and finally completely dried using a SpeedVac. Samples were then stored at $-20^{\circ} \mathrm{C}$ before analysis by MS.

\section{iTRAQ labelling and strong cation exchange}

After protein precipitation in acetone, the samples were dissolved in $20 \mu \mathrm{L}$ of dissolution buffer, reduced, alkylated, trypsin-digested and labelled using the iTRAQ reagents four-plex kit according to the manufacturer's instructions (Applied Biosystems). The resulting peptide solutions from control and DOX-treated soluble protein samples were labelled with iTRAQ114 and iTRAQ117, respectively, and incubated at room temperature for $1 \mathrm{~h}$. Labelled peptides were then pooled and acidified by mix- ing with the cation buffer load iTRAQ reagent for a total volume of $1 \mathrm{ml}$. The peptide mixture was subsequently fractionated by strong cation exchange (SCX) chromatography (See additional file 1 for more details). The elution was monitored by absorbance at 214 and $280 \mathrm{~nm}$ (Additional file 2), and 40 fractions were collected. These experiments were conducted in three different biological replicates. The same protocol was applied to the membrane proteins samples, but labelling was done with iTRAQ115 (control) and iTRAQ116 (DOX-treatment). Each fraction of iTRAQ-labelled sample was dried using a Speedvac, reconstituted in $12 \mu \mathrm{L}$ of buffer $(1 \% \mathrm{v} / \mathrm{v}$ formic acid in $\mathrm{H}_{2} \mathrm{O}$ ) and analysed by nano-liquid chromatography tandem mass spectrometry (nano-LC-MS/MS).

\section{Protein identification by nano-LC MS/MS}

Protein digests extracted from excised DIGE gel spots were analysed by nano-LC-ESI-MS/MS. Purification and analysis were performed on a C18 capillary column using a CapLC system (Waters) coupled to a hybrid quadrupole orthogonal acceleration time-of-flight tandem mass spectrometer (Q-TOF Ultima, Waters). Chromatographic separations were conducted on an RP capillary column (AtlantisTM dC18, $3 \mu \mathrm{m}, 75 \mu \mathrm{m} \times 150 \mathrm{~mm}$ Nano EaseTM, Waters) with a 180-200 nl. $\mathrm{min}^{-1}$ rate of flow (See additional file 1 for more details).

\section{DIGE protein database search}

The data were searched using Mascot software against the $P$. falciparum National Center for Biotechnology Information non-redundant protein database (NCBInr, NIH, Bethesda, MD, March 27th, 2008). Search parameters allowed for one missed tryptic cleavage site, the carbamidomethylation of cysteine, and the possible oxidation of methionine; the precursor and product ion mass error tolerance was $<0.2 \mathrm{Da}$. All identified peptides had a Mascot score greater than 28 (P. falciparum, 12,220 sequences), corresponding to a statistically significant ( $p$ $<0.05)$ confident identification. Moreover, among the positive matches, only protein identifications based on at least two different non-overlapping peptide sequences of more than six amino acids and with a mass tolerance < $0.05 \mathrm{Da}$ were accepted (Additional file 3). These additional validation criteria struck a balance that limited the number of false positive matches without missing real proteins of interest.

\section{ITRAQ protein database search and quantification}

Mascot distiller software (v2.1.1, Matrix Science) was used to convert MassLynx.raw MS/MS data files into mascot generic files (mgf). (See additional file 1 for more details). For protein identification, mgf data files were searched against a mixed file of Homo sapiens and P. falciparum sequences in the NCBInr (NIH, Bethesda, MD) 
protein database $\left(229,804\right.$ sequences on September $12^{\text {th }}$, 2008 for soluble proteins and 230,260 sequences on October 21st, 2008 for membrane proteins) using the MASCOT algorithm (v2.2, Matrix Science). (See additional file 1 for more details). For protein quantification, data analysis was performed with Multi-Q 1.6.1.1. as described elsewhere [29]. The MassLynx.raw data files from the Q-TOF Ultima (Waters) were previously converted into files of the mzXML format by the massWolf program [30]. (See additional file 1 for more details). Geometric means of the ratios of DOX-treated protein to control protein (iTRAQ117/iTRAQ114 for soluble proteins and iTRAQ116/iTRAQ115 for membrane proteins) and the standard deviation were calculated. Proteins with ratios $\leq 0.80$ or $\geq 1.20$ between DOX-treated and untreated experimental conditions were considered regulated proteins, as reported elsewhere [31].

\section{Bioinformatics predictions of biological processes and subcellular localization of identified proteins}

The NCBI GI (GeneInfo Identifier) numbers of $P$. falciparum proteins identified were converted into standard gene names for retrieval from the UniprotKB ID module [32]. Then, in UniprotKB, PlasmoDB accession numbers of proteins were retrieved for further analysis. Biological processes and subcellular localization of differentially expressed proteins were assessed using Gene Ontology annotations downloaded from PlasmoDB [33]. The transit peptides that enable proteins to target the apicoplast were identified by the PlasmoAP tool [34].

\section{Quantitative real-time RT-PCR}

The same parasite cultures used for the proteomic analysis were also used to perform quantitative RT-PCR. Total RNA was extracted with TRIZOL reagent following the manufacturer's recommendations (Invitrogen) and treated with DNase (DNAfree ${ }^{\circ}$, Ambion). Total RNA was quantified with the NanoDrop ND-1000 (Labtech), followed by quality assessment with the 2100 Bioanalyzer (Agilent Technologies) according to the manufacturer's protocol. Acceptable A260/A280 ratios were in the range of 1.8-2.2. Acceptable rRNA ratios (28S/18S) needed to be $>0.9$, and RIN (RNA Integrity Number) values needed to be $>8.0$. Total RNA $(1 \mu \mathrm{g})$ was reverse transcribed with the High-Capacity cDNA Archive Kit as described by the manufacturer (Applied Biosystems). The primer pairs used (Eurogentec), (Additional file 4) were designed with Primer Express software v2.0 (Applied Biosystems). Realtime transcript quantification was performed using a 7900HT Fast Real-Time PCR system (Applied Biosystems). Amplification reactions and the $2^{-\Delta \Delta C t}$ method of relative quantification to estimate relative expression of mRNA targets were performed as previously described [35]. All data were expressed as means \pm standard devia- tion. A two-tailed Student's $t$-test was employed to compare RT-PCR gene expression levels. Statistical significance was defined as $p<0.05$.

\section{Results}

\section{Phenotypic effect of DOX treatment}

Ring stage parasites (>95\%) were incubated with $10 \mu \mathrm{M}$ DOX (i.e. corresponding to $\mathrm{IC}_{50}$ ) for $24 \mathrm{~h}$ followed by a chase period until the end of the successive cycle at $84 \mathrm{~h}$. Then, parasites were collected at the schizont stage for several reasons. First, DOX exerts delayed effects against P. falciparum [36], i.e. exposing the parasites to DOX does not lead to phenotypic effects at the end of the first cycle but instead at the end of the successive cycle. A chase period was applied because continuous DOX exposure leads to almost $100 \%$ parasite lethality. Secondly, this drug has an increased potency against the schizont stage [17], and finally, protein synthesis in parasites is maximal during trophozoïte and schizont stages [37]. At the beginning of the experiments, all cultures had a parasitaemia equal to $2 \%$. At the end of the experiments, parasitaemia obtained from untreated and DOX-treated iRBCs were $7.9 \% \pm 0.7$ and $3.7 \% \pm 0.5$, respectively. Both control and treated cultures were at the schizont stage (> 90\%).

\section{Plasmodium falciparum response to DOX treatment according to 2D-DIGE analysis}

Since membrane-associated proteins are generally underrepresented by two-dimensional electrophoresis, proteins extracted from the schizont stages were separated into soluble and membrane fractions to circumvent this limitation. Then, four biological replicates from untreated or DOX-treated samples were divided into soluble or membrane protein fractions and their protein expression profiles were compared using 2D-DIGE methods. After imaging, DeCyder software was used to detect spot levels that were significantly deregulated by DOX treatment (Figure 1 and additional file 5). Among the three type of gels (with 18-cm 3-10, 4-7 and 6-11 linear IPG strips), a total of 150 spots were considered to be significantly deregulated $(45,45$ and 60 spots respectively in the membranaire protein gels with 4-7 linear IPG strip, in the membranaire protein gels with 6-11 linear IPG strip and in the soluble protein gels with 3-10 linear IPG strip); 95 spots (63\%) were up-regulated and 55 (37\%) spots downregulated in response to DOX treatment $(p<0.05$, Student's $t$-test, and spot ratios $\leq 0.74$ or $\geq 1.35$ ). Thirty five spots $(11,12$ and 12 spots respectively) could not be excised manually (invisible after gel coloration compared to scanning images with Typhoon). Then, 115 spots were submitted to identification by nano LC MS/MS (34, 33 and 48 spots respectively). Sixty seven spots were identified by mass spectrometry (MS) (15, 20 and 32 spots respectively). Forty eight spots were not identified (19, 13 
Table 1: Differentially expressed proteins in DoX-treated parasites (DIGE quantification).

\begin{tabular}{|c|c|c|c|c|c|c|c|c|}
\hline $\begin{array}{l}\text { Accession } \\
\text { number }\end{array}$ & Name & Spot & $\begin{array}{l}\text { MASCOT } \\
\text { score }\end{array}$ & $\begin{array}{l}\text { Peptides } \\
\text { matched }\end{array}$ & Ratios $^{a}$ & Biological process ${ }^{b}$ & $\begin{array}{l}\text { Predicted } \\
\text { Localizationc }\end{array}$ & Fractiond \\
\hline \multirow[t]{7}{*}{ PF13_0304 } & Elongation factor 1 alpha & 1078 & 236 & 5 & $2.85^{*}$ & Translation & Cytoplasm & S \\
\hline & & 1111 & 226 & 4 & $2.65^{*}$ & & & S \\
\hline & & 1143 & 246 & 5 & $2.42^{*}$ & & & S \\
\hline & & 1026 & 309 & 6 & $2.31^{*}$ & & & S \\
\hline & & 848 & 411 & 9 & $2.04^{* *}$ & & & $M(2)$ \\
\hline & & 833 & 306 & 6 & $2.03^{* *}$ & & & $M(2)$ \\
\hline & & 1168 & 254 & 6 & $1.65^{*}$ & & & s \\
\hline PF13_0143 & $\begin{array}{l}\text { Phosphoribosylpyrophosphate } \\
\text { synthetase }\end{array}$ & 964 & 174 & 3 & $2.36^{*}$ & Carbohydrate metabolism & Apicoplast & $M(2)$ \\
\hline PFB0445c & DEAD box helicase, UAP56 & 2246 & 138 & 2 & $2.25^{*}$ & Nucleic acid binding & Unknown & s \\
\hline \multirow[t]{2}{*}{ PFI1105w } & Phosphoglycerate kinase & 1025 & 515 & 10 & $2.14^{*}$ & Carbohydrate metabolism & Unknown & $S$ \\
\hline & & 993 & 343 & 6 & $2.07^{*}$ & & & S \\
\hline \multirow[t]{3}{*}{ PF14_0598 } & $\begin{array}{l}\text { Glyceraldehyde-3-phosphate } \\
\text { dehydrogenase }\end{array}$ & 1288 & 114 & 2 & $2.13^{*}$ & Carbohydrate metabolism & Cytoplasm & s \\
\hline & & 1295 & 276 & 5 & $1.89^{*}$ & & & S \\
\hline & & 1325 & 472 & 8 & $1.81^{*}$ & & & s \\
\hline PFI1090w & $\begin{array}{l}\text { S-adenosylmethionine } \\
\text { synthetase }\end{array}$ & 1236 & 88 & 2 & $1.99 *$ & $\begin{array}{l}\text { One carbon compound } \\
\text { metabolism }\end{array}$ & Cytoplasm & $M(1)$ \\
\hline \multirow[t]{4}{*}{ PFF1300w } & Putative pyruvate kinase & 800 & 217 & 4 & $1.95^{*}$ & Carbohydrate metabolism & Apicoplast & S \\
\hline & & 788 & 120 & 3 & $1.86^{*}$ & & & s \\
\hline & & 1672 & 110 & 2 & $1.70^{*}$ & & & $M(1)$ \\
\hline & & 553 & 149 & 3 & $1.61^{* *}$ & & & $M(2)$ \\
\hline PF14_0368 & 2-Cys peroxiredoxin & 1821 & 116 & 2 & $1.94^{*}$ & Anti oxidative stress & Unknown & $M(2)$ \\
\hline PFE0690c & Rab1 protein & 2221 & 171 & 4 & $1.89^{* *}$ & Intracellular protein transport & Cytoplasm & S \\
\hline PF11_0396 & Protein phosphatase $2 \mathrm{C}$ & 2309 & 144 & 2 & $1.84^{*}$ & $\begin{array}{l}\text { Protein amino acid } \\
\text { dephosphorylation }\end{array}$ & Cytoplasm & s \\
\hline PFF1335c & $\begin{array}{l}\text { 4-methyl-5(B-hydroxyethyl)- } \\
\text { thiazol Monophosphate } \\
\text { biosynthesis enzyme }\end{array}$ & 2198 & 282 & 5 & $1.69 *$ & Thiamin biosynthesis & Cytoplasm & $\mathbf{s}$ \\
\hline \multirow[t]{2}{*}{ MAL13P1.283 } & TCP-1/cpn60 chaperonin family & 958 & 828 & 13 & $1.64^{*}$ & Protein folding & Cytoplasm & $M(1)$ \\
\hline & & 936 & 315 & 6 & $1.38^{*}$ & & & $M(1)$ \\
\hline
\end{tabular}


Table 1: Differentially expressed proteins in DOX-treated parasites (DIGE quantification). (Continued)

\begin{tabular}{|c|c|c|c|c|c|c|c|c|}
\hline PFF1155w & Hexokinase & 795 & 123 & 3 & $1.61 *$ & Carbohydrate metabolism & Unknown & $\mathbf{S}$ \\
\hline \multirow[t]{2}{*}{ PF14_0425 } & Fructose-bisphosphate aldolase & 1180 & 552 & 10 & $1.60^{* * *}$ & Carbohydrate metabolism & Unknown & $\mathrm{s}$ \\
\hline & & 917 & 561 & 10 & $1.43^{*}$ & & & $M(2)$ \\
\hline PF14_0076 & Plasmepsin 1 precursor & 1406 & 215 & 4 & $1.58^{* * *}$ & Haemoglobin Catabolism & Membrane & $\mathrm{S}$ \\
\hline MAL8P1.69 & 14-3-3 protein & 1647 & 71 & 2 & $1.54^{*}$ & Protein folding & Unknown & $\mathbf{s}$ \\
\hline PF08_0131 & 1-Cys peroxiredoxin & 2251 & 83 & 2 & $1.52^{*}$ & Anti oxidative stress & Unknown & $M(1)$ \\
\hline PF08_0074 & DNA/RNA-binding Protein Alba & 1237 & 113 & 3 & $1.51 *$ & Nucleic acid binding & Nucleus & $M(2)$ \\
\hline PF14_0486 & Elongation factor 2 & 1264 & 164 & 4 & $1.48 *$ & Translation & Cytoplasm & $\mathbf{S}$ \\
\hline PF13_0214 & Elongation factor 1-gamma & 1984 & 77 & 2 & $1.47^{*}$ & Translation & Apicoplast & $\mathrm{s}$ \\
\hline \multirow[t]{2}{*}{ PF10_0155 } & Enolase & 1066 & 439 & 8 & $1.43^{* *}$ & Carbohydrate metabolism & Cytoplasm & $M(1)$ \\
\hline & & 1089 & 584 & 10 & $1.35^{*}$ & & & $M(1)$ \\
\hline PFL0960w & $\begin{array}{l}\text { D-ribulose-5-phosphate 3- } \\
\text { epimerase }\end{array}$ & 2248 & 94 & 2 & $1.35^{* *}$ & Carbohydrate metabolism & Unknown & $M(1)$ \\
\hline PF11_0117 & Replication factor $C$ subunit 5 & 1020 & 106 & 2 & $0.70^{*}$ & DNA replication & Nucleus & $M(2)$ \\
\hline PF08_0109 & Proteasome subunit alpha type 5 & 2057 & 79 & 2 & $0.63^{*}$ & $\begin{array}{l}\text { Ubiquitin dependent protein } \\
\text { catabolism }\end{array}$ & Unknown & $\mathrm{S}$ \\
\hline PFL0185c & Nucleosome assembly protein 1 & 967 & 170 & 4 & $0.61^{* *}$ & Nucleosome assembly & Nucleus & $\mathrm{s}$ \\
\hline PF11_0313 & 605 ribosomal protein $\mathrm{PO}$ & 2081 & 100 & 2 & $0.60^{*}$ & Translation & $\begin{array}{l}\text { Mitochondrio } \\
\mathrm{n}\end{array}$ & $M(1)$ \\
\hline PF11_0282 & $\begin{array}{l}\text { Deoxyuridine } 5 \text { '-triphosphate } \\
\text { nucleotidohydrolase }\end{array}$ & 2332 & 306 & 5 & $0.60^{*}$ & DNA replication & Nucleus & $\mathrm{S}$ \\
\hline MAL8P1.95 & Conserved Plasmodium protein & 1532 & 241 & 3 & $0.58 *$ & Unknown & Unknown & $\mathbf{S}$ \\
\hline PF14_0678 & Exp-2 & 1421 & 153 & 3 & $0.57^{* *}$ & Unknown & Membrane & $M(1)$ \\
\hline PF11_0183 & GTP-binding nuclear protein ran/tc4 & 1451 & 98 & 2 & $0.49^{*}$ & Nucleus transport & Nucleus & $M(2)$ \\
\hline PF13_0033 & $26 \mathrm{~S}$ proteasome regulatory subunit & 854 & 341 & 8 & $0.47^{*}$ & $\begin{array}{l}\text { Ubiquitin dependent protein } \\
\text { catabolism }\end{array}$ & Nucleus & $M(2)$ \\
\hline PF14_0359 & HSP40, Subfamily A & 648 & 204 & 4 & $0.35^{*}$ & Protein folding & Unknown & $M(2)$ \\
\hline
\end{tabular}




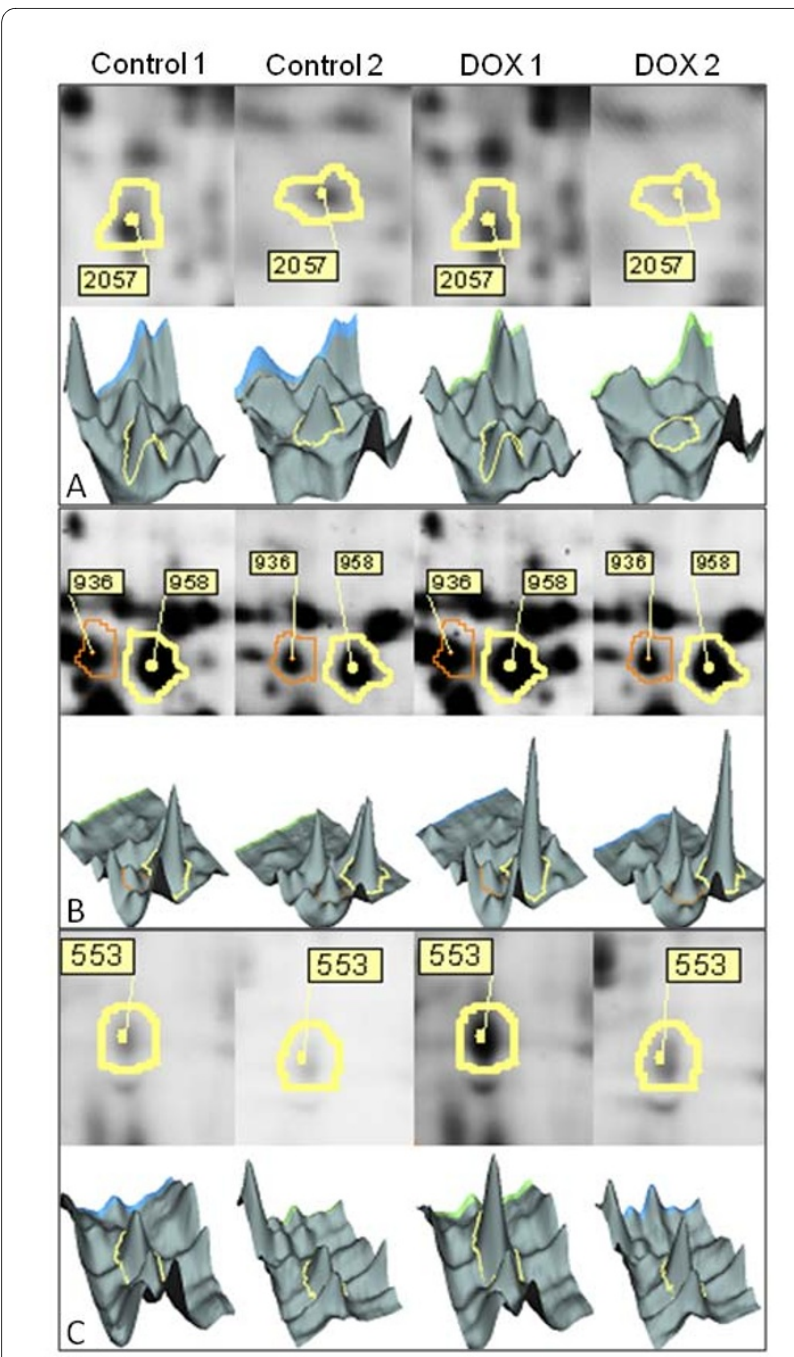

Figure 1 Examples of 2D and 3D representations of fluorescence intensity of spots that were up and down regulated in response to DOX treatment, as visualized with Decyder software in 2DDIGE analysis. (A) In the soluble proteins gel with pl 3-10, spot 2057 was down regulated under DOX treatment and was identified as a putative protein: proteasome subunit alpha type 5 (PF08_0109). (B) In the membrane proteomic map with pl 4-7, spots 936 and 958 were up regulated under DOX treatment and identified as isoforms of the same putative protein: TCP-1/cpn60 chaperon family (MAL13P1.283). (C) In the membrane proteomic map with pl 6-11, spot 553 was up regulated and identified as a putative pyruvate kinase (PFF1300w)

and 16 spots respectively) and 20 spots (5, 9 and 6 spots respectively) were not retained, because comigration of proteins confounded the ability to identify individual proteins. Finally, 47 protein spots were identified (Table 1). However, some proteins were detected in more than one spot, indicating different isoforms. A total of 32 distinct proteins, according to their accession numbers, were finally identified (Figure 1) (Table 1, peptide details in Additional file 2). Among these proteins, 22 were up-regulated, and 10 were down-regulated. They were classified according to their biological functions in Table 1. Some proteins were identified as being involved in primary metabolism (e.g., carbohydrate, protein and amino-acid metabolism, and DNA replication). Proteins involved in anti-oxidative stress (PF08_0131, 1-Cys peroxiredoxin in spot 2251 and PF14_0368, 2-Cys peroxiredoxin in spot 1821) and two proteins with unknown functions were also identified. Several isoforms of the same protein (PF10_0155, enolase in spots 1066 and 1089; PF14_0598, glyceraldehyde-3-phosphate dehydrogenase in spots 1288, 1295 and 1325 in Figure 1A and Table 1) were identified in adjacent spots.

\section{Plasmodium falciparum response to DOX treatment according to ITRAQ analysis}

The same soluble and membrane protein extracts used for 2D-DIGE analysis were subjected to iTRAQ analysis. For this analysis, three biological replicates from untreated or DOX-treated parasites were digested, and the peptides were labelled with different isobaric tags. Of the soluble protein samples, 422 proteins were confidently identified including 246 plasmodial proteins (58.3\%) and 176 human proteins $(41.7 \%)$ in the three biological replicates. Among them, 169 were quantified (i.e., with at least 4 labelled, non-degenerated peptides), including 14 human proteins $(8.3 \%)$ and 155 plasmodial proteins $(91.7 \%)$. Twenty-two proteins displayed significant differences in expression levels (proteins with fold change $\leq 0.80$ or $\geq 1.20$ were considered as differentially expressed proteins); 18 of these proteins were up-regulated, and four were down-regulated following DOX exposure (Table 2). In membrane protein samples, 308 proteins were confidently identified, including 204 plasmodial proteins $(66.2 \%)$ and 104 human proteins $(33.8 \%)$ in the three biological replicates. Among them, 156 were quantified, including 9 human proteins (5.8\%) and 147 plasmodial proteins $(94.2 \%)$. Eighteen proteins displayed significant differences in expression; 14 of these proteins were up-regulated and four were down-regulated following DOX exposure. In total, 40 proteins were differentially expressed in response to DOX treatment (Table 2); $80 \%$ were up-regulated (32 out of 40 ), and $20 \%$ were down-regulated ( 8 out of 40 ). The proteins up-regulated by DOX treatment were associated with haemoglobin catabolism, protein synthesis, protein processing, antioxidative stress and phospholipid metabolism. Downregulated proteins were mostly associated with protein synthesis/processing or nuclear transport. A substantial proportion of the proteins $(20 \%, 8$ out of 40$)$ have not been assigned to a biological function yet. Two up-regulated proteins were identified as human proteins: biliverdine reductase and S100-calcium binding protein A4. Their function and location in human cells were precised in Table 2. 
Table 2: Differentially expressed proteins in DOX-treated parasites (iTRAQ quantification).

\begin{tabular}{|c|c|c|c|c|c|}
\hline $\begin{array}{l}\text { Accession } \\
\text { numbera }\end{array}$ & Name & $\begin{array}{l}\text { Peptides } \\
\text { quantified }\end{array}$ & Ratios \pm SD & $\begin{array}{l}\text { Biological } \\
\text { process }^{b}\end{array}$ & $\begin{array}{l}\text { Predicted } \\
\text { Localizationc }\end{array}$ \\
\hline PF13_0130 & Vacuolar ATP synthase subunit $g$ & 3 & $2.47 \pm 1.07$ & $\begin{array}{l}\text { Vacuolar } \\
\text { acidification }\end{array}$ & Membrane \\
\hline PFC0735w & $\begin{array}{l}40 \mathrm{~S} \text { ribosomal protein } \mathrm{S} 15 \mathrm{~A} \\
\text { putative }\end{array}$ & 3 & $1.93 \pm 0.71$ & Translation & Cytoplasm \\
\hline PF08_0074 & $\begin{array}{l}\text { DNA/RNA-binding Protein } \\
\text { Alba, putative }\end{array}$ & 6 & $1.82 \pm 0.08$ & $\begin{array}{l}\text { Nucleic acid } \\
\text { binding }\end{array}$ & Nucleus \\
\hline MAL13P1.214 & $\begin{array}{l}\text { Phosphoethanolamine N- } \\
\text { methyltransferase }\end{array}$ & 6 & $1.79 \pm 0.47$ & $\begin{array}{l}\text { Phosphatidylcholi } \\
\text { ne biosynthesis }\end{array}$ & Unknown \\
\hline PF10_0068 & RNA binding protein putative & 3 & $1.76 \pm 0.16$ & $\begin{array}{l}\text { Nucleic acid } \\
\text { binding }\end{array}$ & Apicoplast \\
\hline PFB0340c & Serine repeat antigen 5 (SERA-5) & 8 & $1.76 \pm 0.37$ & Proteolysis & Unknown \\
\hline PFC0920w & Histone $\mathrm{H} 2 \mathrm{~A}$ variant putative & 3 & $1.59 \pm 0.25$ & $\begin{array}{l}\text { Nucleosome } \\
\text { assembly }\end{array}$ & Apicoplast \\
\hline PFI1090w & $\begin{array}{l}\text { S-adenosylmethionine } \\
\text { synthetase }\end{array}$ & 5 & $1.57 \pm 0.25$ & $\begin{array}{l}\text { One carbon } \\
\text { compound } \\
\text { metabolism }\end{array}$ & Cytoplasm \\
\hline PFB0915w & Liver stage antigen-3 & 4 & $1.54 \pm 0.04$ & Unknown & Membrane \\
\hline PFL1545c & Chaperonin cpn60 & 3 & $1.52 \pm 0.40$ & Protein folding & Apicoplast \\
\hline PFF0835w & Conserved Plasmodium protein & 5 & $1.50 \pm 0.01$ & Unknown & Unknown \\
\hline PF08_0110 & Rab18 GTPase & 3 & $1.49 \pm 0.13$ & $\begin{array}{l}\text { Intracellular } \\
\text { protein transport }\end{array}$ & Cytoplasm \\
\hline PF14_0078 & Plasmepsin III|HAP protein & 6 & $1.48 \pm 0.04$ & $\begin{array}{l}\text { Haemoglobin } \\
\text { Catabolism }\end{array}$ & Membrane \\
\hline PF14_0324 & $\begin{array}{l}\text { Hsp } 70 / H s p 90 \text { organizing protein } \\
\text { putative }\end{array}$ & 17 & $1.46 \pm 0.21$ & Protein folding & Unknown \\
\hline PF10_0115 & QF122 antigen & 9 & $1.45 \pm 0.04$ & $\begin{array}{l}\text { Nucleic acid } \\
\text { binding }\end{array}$ & Apicoplast \\
\hline PF14_0655 & RNA helicase-1 putative & 5 & $1.44 \pm 0.01$ & Translation & Cytoplasm \\
\hline PF14_0201 & Surface protein putative $\mathrm{Pf} 113$ & 6 & $1.44 \pm 0.07$ & Unknown & Membrane \\
\hline PF14_0486 & Elongation factor 2 & 16 & $1.41 \pm 0.30$ & Translation & Cytoplasm \\
\hline PF10_0323 & $\begin{array}{l}\text { Early transcribed membrane } \\
\text { protein } 10.2\end{array}$ & 4 & $1.40 \pm 0.08$ & Unknown & Membrane \\
\hline PFL1170w & $\begin{array}{l}\text { Polyadenylate-binding protein } \\
\text { putative }\end{array}$ & 12 & $1.35 \pm 0.05$ & Transcription & Unknown \\
\hline gi|544759 & Biliverdin reductase $B$ & 2 & $1.35 \pm 0.16$ & $\begin{array}{l}\text { Porphyrin } \\
\text { metabolism }\end{array}$ & Cytoplasm \\
\hline PFE0870w & $\begin{array}{l}\text { Transcriptional regulator } \\
\text { putative }\end{array}$ & 4 & $1.34 \pm 0.10$ & Transcription & Nucleus \\
\hline gi|4506765 & S100 calcium-binding protein A4 & 2 & $1.34 \pm 0.06$ & Cell growth & Cytoplasm \\
\hline PF11_0062 & Histone $\mathrm{H} 2 \mathrm{~B}$ & 7 & $1.34 \pm 0.12$ & $\begin{array}{l}\text { Nucleosome } \\
\text { assembly }\end{array}$ & Apicoplast \\
\hline PF14_0391 & $\begin{array}{l}60 S \text { ribosomal protein } \mathrm{L} 1 \\
\text { putative }\end{array}$ & 2 & $1.32 \pm 0.13$ & Translation & Cytoplasm \\
\hline MAL8P1.69 & 14-3-3 protein & 6 & $1.30 \pm 0.19$ & Protein folding & Unknown \\
\hline MAL13P1.56 & M1-family aminopeptidase & 5 & $1.28 \pm 0.06$ & $\begin{array}{l}\text { Haemoglobin } \\
\text { Catabolism }\end{array}$ & Apicoplast \\
\hline PF14_0439 & $\begin{array}{l}\text { Leucine aminopeptidase } \\
\text { putative }\end{array}$ & 4 & $1.27 \pm 0.18$ & $\begin{array}{l}\text { Haemoglobin } \\
\text { Catabolism }\end{array}$ & Apicoplast \\
\hline PF08_0096 & RNA helicase putative & 3 & $1.24 \pm 0.04$ & Transcription & Unknown \\
\hline
\end{tabular}


Table 2: Differentially expressed proteins in DOX-treated parasites (iTRAQ quantification). (Continued)

\begin{tabular}{|c|c|c|c|c|c|}
\hline PF08_0131 & 1-Cys peroxiredoxin & 9 & $1.22 \pm 0.15$ & $\begin{array}{l}\text { Anti oxidative } \\
\text { stress }\end{array}$ & Unknown \\
\hline PFE0585c & $\begin{array}{l}\text { Myo-inositol 1-phosphate } \\
\text { synthase putative }\end{array}$ & 10 & $1.22 \pm 0.03$ & $\begin{array}{l}\text { Phospholipid } \\
\text { biosynthetic } \\
\text { process }\end{array}$ & Unknown \\
\hline PFL1720w & Serine hydroxymethyltransferase & 3 & $1.21 \pm 0.01$ & $\begin{array}{l}\text { One carbon } \\
\text { compound } \\
\text { metabolism }\end{array}$ & Unknown \\
\hline PF14_0167 & Prefoldin subunit 2 putative & 4 & $0.80 \pm 0.05$ & Protein folding & Cytoplasm \\
\hline PFI1780w & $\begin{array}{l}\text { Plasmodium exported protein } \\
\text { (PHISTC) }\end{array}$ & 2 & $0.80 \pm 0.19$ & Unknown & Apicoplast \\
\hline MAL8P1.95 & Conserved Plasmodium protein & 5 & $0.76 \pm 0.09$ & Unknown & Unknown \\
\hline PFE0290c & Conserved Plasmodium protein & 3 & $0.75 \pm 0.06$ & Unknown & Unknown \\
\hline PFA0110w & DnaJ protein putative & 5 & $0.74 \pm 0.24$ & Protein folding & Membrane \\
\hline PF08_0087 & Importin alpha putative & 5 & $0.73 \pm 0.12$ & Nucleus transport & Nucleus \\
\hline PFD0090c & $\begin{array}{l}\text { Plasmodium exported protein } \\
\text { (PHISTa) }\end{array}$ & 4 & $0.61 \pm 0.14$ & Unknown & Apicoplast \\
\hline PF11_0351 & $\begin{array}{l}\text { Heat shock protein hsp70 } \\
\text { homologue }\end{array}$ & 6 & $0.54 \pm 0.04$ & Protein folding & Mitochondrion \\
\hline
\end{tabular}

In bold: differentially expressed proteins commonly identified in DIGE and iTRAQ. aPlasmoDB accession number, except for two human proteins (NCBI accession number). b ${ }^{b}$ ata depicted from PlasmoDB (gene ontology biological process annotation). cData depicted from PlasmoDB (gene ontology location annotation or PlasmoAP to predict apicoplast addressing).

\section{Comparison of differentially expressed proteins identified by 2D-DIGE and ITRAQ}

Of the deregulated proteins identified by DIGE, 19\% (six out of 32) were also identified by iTRAQ. The proteins identified by both approaches (DIGE and ITRAQ) were similarly deregulated; for example, S-adenosylmethionine synthetase (DIGE fold change of 1.99 in Table 1 and 1.57 with iTRAQ in Table 2) and 1-Cys peroxiredoxin (fold change of 1.52 with DIGE and 1.22 with iTRAQ). The metabolic processes in which the proteins are involved are similar and, for the most part, changes in protein expression levels were similar between the two approaches (Figure 2). The main metabolic systems identified by both proteomics approaches were protein metabolism, the anti-oxidant response mechanism, nucleic acid binding and transport mechanisms. Both approaches revealed a down-regulation of proteins involved in protein synthesis metabolism and transport mechanism and an up-regulation of proteins involved in protein metabolism and anti-oxidant response mechanisms (Figure 2). However, proteins involved in nucleic acid binding were characterized differently by the two methods; these proteins were up-regulated according to the iTRAQ data and down-regulated according to the DIGE data. Proteins involved in carbohydrate metabolism were all up-regulated and only identified by the DIGE method (Table 1). In addition, proteins involved in specific metabolic pathways were only identified by
iTRAQ (Figure 2 and Table 2). Those proteins identified by iTRAQ alone were either membrane proteins involved in vacuolar acidification or enzymes involved in phospholipid metabolism (Table 2). Fifteen soluble proteins were identified in the soluble fractions but not in the membrane fractions (Table 1). Fourteen proteins were identified only in membrane fractions, but only two are actually thought to belong to the membrane, calling into question the effectiveness of the 2D-PAGE approach for characterising membrane proteins. The iTRAQ method, in contrast, allowed identification and quantification of a large number of high molecular weight proteins and membrane proteins (Table 2).

\section{Subcellular localization of regulated proteins}

As predicted by gene ontology in PlasmoDB and PlasmoAP (for apicoplast addressing), the cellular localization (Table 1 and Table 2) of the 64 differentially regulated plasmodial proteins identified by the two proteomic approaches was as follows: $21 \%$ in the cytoplasm, $19 \%$ in the apicoplast, $13 \%$ in the membrane, $13 \%$ in the nucleus, $5 \%$ in the mitochondria and 29\% unknown. Cytoplasmic, apicoplastic and membrane proteins were generally up-regulated, while nuclear and mitochondrial proteins were more often down-regulated (Figure 3). All of the identified apicoplastic proteins were encoded by the nuclear genome of $P$. falciparum and not by its plastid genome. 


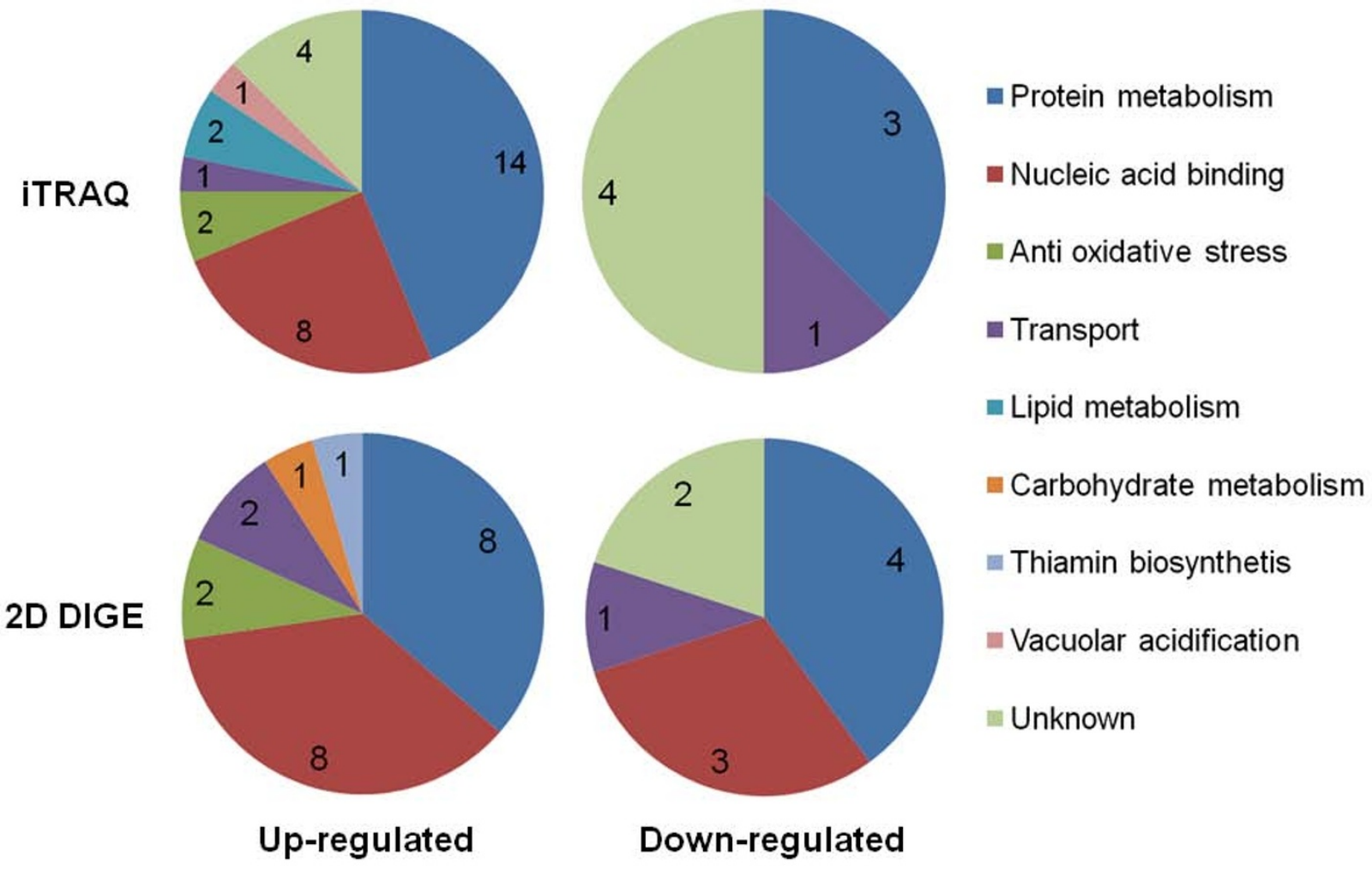

Figure 2 Functional classification of differentially expressed proteins under DOX treatment identified in iTRAQ and DIGE experiments.

\section{RT-PCR quantifications}

To validate the proteomics results, quantitative RT-PCR was performed because antibodies against $P$. falciparum are not commercially available, and the proteomics data suggest that apicoplast function was particularly perturbed by DOX-treatment. Thus, three apicoplast transcripts were chosen to evaluate the modifications observed in this organelle following DOX-treatment. PFI1090w (the S-adenosylmethionine synthetase) and

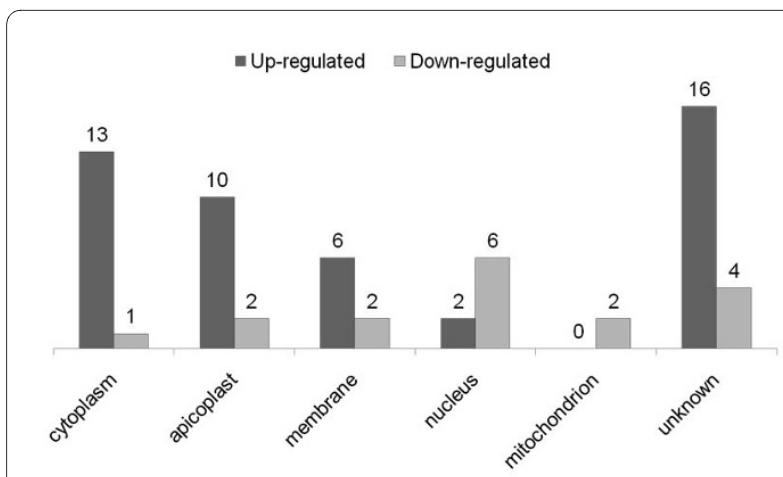

Figure 3 Number of differentially expressed proteins, identified by ITRAQ and DIGE experiments, corresponding to different functions and subcellular localizations.
MAL8P1.95 (a conserved Plasmodium protein), which had similar expression profiles (up and down regulation respectively) according to both DIGE and iTRAQ, also had similar expression profiles at the transcript level (Table 3). PF14_0439 (leucine aminopeptidase) was shown to be upregulated by iTRAQ analysis and was also up-regulated at the transcript level. Moreover, mRNA for the PftufA, PfsufB and $P f c l p C$ proteins encoded by the plastid genome, which were not quantified at the protein level by DIGE or iTRAQ, were down-regulated at the transcript level. Two transcripts of PF07_0033 (CG4) and PFE1195w (Karyopherin beta) proteins were used as positive controls in RT-PCR experiments (Their qRT-PCR ratios were $1.05 \pm 0.09$ and $0.98 \pm 0.12$ respectively) because they were not deregulated in iTRAQ proteomic approach (iTRAQ ratios were $1.01 \pm 0.03$ and $1.07 \pm 0.05$ respectively), (Table 3 ).

\section{Discussion}

In the present study, proteome changes was researched in Plasmodium falciparum following DOX treatment in order to clarify the action mechanisms of this drug using two proteomic approaches, 2D-DIGE and iTRAQ. These techniques have been shown to be complementary in studying protein changes as they have distinct physico- 
Table 3: Quantitative RT-PCR results.

\begin{tabular}{|c|c|c|c|c|}
\hline Accession nr & Description & DIGE ratios & iTRAQ ratios & qRT-PCR ratios \\
\hline PFCOMPIRB-TufA & TufA & NA & NA & $0.30 \pm 0.04$ \\
\hline PFCOMPIRB-SufB & SufB & NA & NA & $0.32 \pm 0.12$ \\
\hline PFCOMPIRB-CIpC & $\mathrm{ClpC}$ & NA & NA & $0.26 \pm 0.08$ \\
\hline PFI1090w & $\begin{array}{l}\text { S-adenosylmethionine } \\
\text { synthetase }\end{array}$ & 1.99 & $1.57 \pm 0.25$ & $1.72 \pm 0.16$ \\
\hline MAL8P1.95 & $\begin{array}{l}\text { Conserved } \\
\text { Plasmodium protein }\end{array}$ & 0.57 & $0.76 \pm 0.09$ & $0.44 \pm 0.03$ \\
\hline PF14_0439 & $\begin{array}{l}\text { Leucine } \\
\text { aminopeptidase } \\
\text { putative }\end{array}$ & NA & $1.27 \pm 0.18$ & $1.48 \pm 0.23$ \\
\hline PF07_0033 & $\mathrm{Cg} 4$ protein & NA & $1.01 \pm 0.03$ & $1.05 \pm 0.09$ \\
\hline PFE1195w & Karyopherin beta & NA & $1.07 \pm 0.05$ & $0.98 \pm 0.12$ \\
\hline
\end{tabular}

${ }^{a} \mathrm{qRT}-\mathrm{PCR}$ ratios correspond to the relative expression of target mRNA between the DOX treated and the control (mean of three biological replicates). NA: not available.

chemical properties that favour identification of different proteins [38,39]; that is the reason why a $19 \%$ overlap was observed between deregulated proteins identified by the both methods. Analysis of the DIGE results detected differentially expressed proteins with PTMs (post translational modifications) after DOX treatment (Table 1 and Figure 1). In particular, enolase and aldolase have previously been reported to possess several differentially expressed isoforms during the schizont stages of $P$. falciparum [40]; these two proteins are localized in Maurer's cleft [41] and in the food vacuole [42]. However, little is known about the role of these PTMs in the plasmodial regulation of protein expression under either physiological conditions or anti-malarial treatment.

Few proteomic studies have been undertaken to elucidate the mechanisms of drug action in P. falciparum but all share some common features with the present work $[22,24,43]$. After exposure to anti-malarial treatment, proteome analysis has generally revealed a low number of differentially expressed proteins with an upregulation of proteins involved in glycolysis, chaperoning or redox metabolism. In a stable isotope labelling experiment after artemisinin and chloroquine treatment in schizont stages of $P$. falciparum, among more than 800 quantified proteins, only 41 and 38 were up-regulated, respectively [24]. However, none of these proteins were associated with heat shock response or glycolysis functions, probably because the design of the study did not allow it, e.g. the SILAC method, which explores only newly synthesized proteins, was used. In a gel-based study, arthemeter and lumefantrine treatment were respectively associated with an up-regulation of 22 and 41 proteins [43]. In another study, chloroquine treatment increased the number of oxidized proteins in the schizont stage of parasites [22].
In these two last studies, four glycolysis enzymes (enolase, aldolase, phosphoglycerate kinase and glyceraldehyde-3-phosphate dehydrogenase) and one heat shock protein (HSP 70 homolog) were commonly identified as up-regulated proteins under lumefantrine or chloroquine treatment, which was similar to the results seen under DOX treatment. The increased expression of redox metabolism proteins (1-Cys peroxiredoxin, 2-Cys peroxiredoxin) and 11 other "associated proteins" (Table 1 and Table 2), which have been recently shown to be potential targets of thioredoxin, glutaredoxin and plasmoredoxin [44], might represent another non-specific common feature of parasite responses to drug treatment.

Alternately, some metabolic pathways (Figure 4) might represent a specific response of parasites to DOX. Several studies have shown that tetracyclines, which are members of the DOX family, directly inhibit mitochondrial protein synthesis $[13,45,46]$. This inhibition would lead to a decrease in the mitochondrial respiratory chain activity [16] because the plasmodial mitochondrial genome encodes cytochrome $c$ oxidase subunits I and III and apocytochrome $b$. The mitochondrial respiratory chain is coupled to dihydroorotate dehydrogenase activity, which has been shown to be depressed under tetracycline treatment [14]. This enzyme is involved in de novo pyrimidine biosynthesis, and its inhibition is associated with decreased levels of nucleotides and deoxynucleotides in $P$. falciparum in response to tetracycline treatment [15]. DOX inhibition of mitochondrial protein synthesis could be responsible for DNA replication impairment as suggested in the present study, i.e. replication factor $\mathrm{C}$ subunit 5 and deoxyuridine 5 -3P nucleotidohydrolase were down-regulated (Figure 4). 


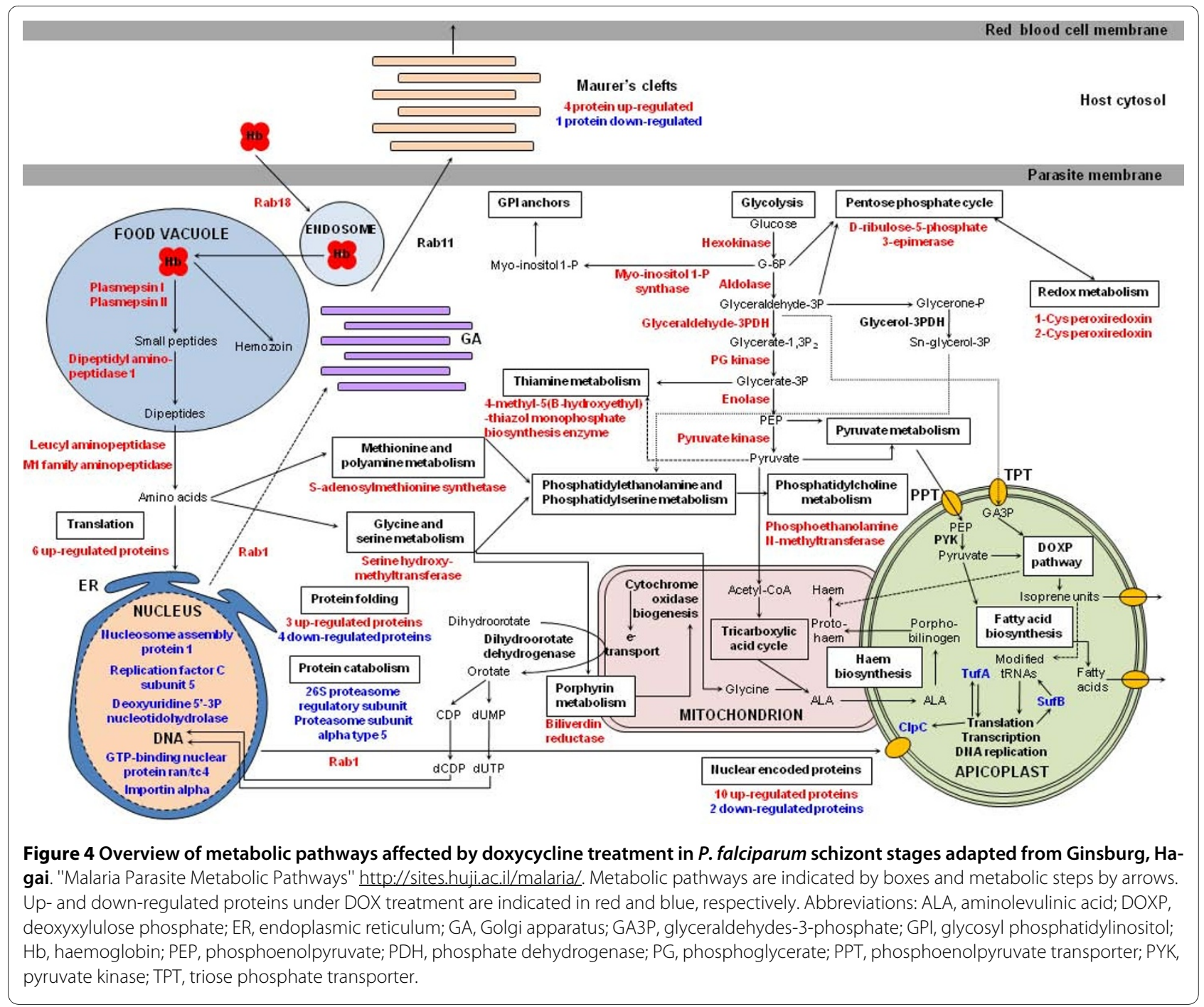

Two recent works have confirmed specific action by the cyclines on the $P$. falciparum apicoplast $[17,18]$; replication and transcription of the plastid genome as well as the import of nuclear encoded proteins into the plastid matrices' were inhibited in response to cycline treatment. Cyclines are assumed to inhibit plastid protein synthesis, but the precise mechanism of action has not yet been identified. The apicoplast genome encodes different tRNAs, rRNA, TufA (a translational elongation factor), SufB (involved in iron metabolism and modification of tRNAs [47]), ClpC (a protease required for nuclearencoded protein import into the apicoplast) and a DNA dependent RNA polymerase (involved in transcription). This organelle is implicated in fatty acid and isoprenoid precursor synthesis and in heme biosynthesis in tight association with mitochondria [48]. In the present study, $\mathrm{ClpC}$, TufA and SufB were found to be down-regulated under DOX treatment, but only at the transcriptional level. The inhibition of $\mathrm{ClpC}$ could explain the defect in protein import into the apicoplast and consequently the overexpression of 12 encoded nuclear proteins that are localized to the apicoplast (Figure 4).

\section{Conclusions}

The present study has given the first insights into changes in protein regulation in $P$. falciparum upon DOX treatment, suggesting that $P$. falciparum apicoplasts and mitochondria are the targets of DOX. It has also confirmed that 2D-DIGE and iTRAQ are powerful and complementary techniques in studying protein changes in response to drug treatment. However, more experiments will be needed to characterize the specific molecular mechanisms of DOX treatment. In order to prove that DOX inhibits plastid or mitochondrial translational further biochemical approaches would probably be required. 


\section{Additional material}

\section{Additional file 1 Methods. Supplementary Methods Additional file $\mathbf{2}$ SCX separation profiles of ITRAQ labelled peptides from the three biological replicates of soluble proteins at $214 \mathrm{~nm}$. Supplementary Figure}

Additional file 3 Differentially expressed proteins in DOX-treated parasites identified from differential 2D-DIGE (pH 3-10, 4-7 and 6-11) analysis. Supplementary Table

Additional file 4 Primer pairs used in quantitative RT-PCR. Supplementary Table

Additional file 5 The 2D gel proteomic map of schizont stages of $P$. falciparum. Spots with a significant intensity change between doxycycline treatment and untreated are indicated by a circle in the soluble proteomic map with pl 3-10 (A), and in the membrane proteomic map with pl 4-7 (B) and pl 6-11 (C). (D) Enlargement of panel (A) to focus on differentially expressed protein spots following DOX treatment.

Abbreviations

DOX: doxycycline; RBCs: red blood cells; iRBCs: infected red blood cells.

\section{Competing interests}

The authors declare that they have no competing interests.

\section{Authors' contributions}

$\mathrm{SB}, \mathrm{LA}, \mathrm{TF}, \mathrm{CR}$ and $\mathrm{BP}$ conceived and designed the experiments, SB, LA, MB, NW and $A F$ performed the experiments, $S B, L A, M B, E B, N W, A F$ and $C R$ analyzed the data, $\mathrm{MB}, \mathrm{EB}$ and SG contributed reagents/materials/analysis tools, and $\mathrm{SB}, \mathrm{LA}$ $\mathrm{CR}$ and $\mathrm{BP}$ wrote the paper.

\section{Acknowledgements}

The authors thank R. Amalvict, E. Baret and J. Mosnier from the Institut de Recherche Biomédicale des Armées, Antenne de Marseille, Institut de Médec ine Tropicale du Service de Santé des Armées in Marseilles for their technical support.

The authors acknowledge the financial support of the Délégation Générale pour l'Armement and the Direction Centrale du Service de Santé des Armées (grant no. 06CO009).

\section{Author Details}

1 Unité de Recherche en Biologie et Epidémiologie Parasitaires, Institut de Recherche Biomédicale des Armées, Antenne de Marseille, BP 60109, 13262 Marseille Cedex 07, France, 2 Unité de Recherche en Maladies Infectieuses et Tropicales Emergentes, UMR 6236, Marseille, France, ${ }^{3}$ Centre d'Analyses Protéomiques de Marseille, IFR 137, Marseille, France, 4Unité de Recherche en Physiologie et Pharmacologie Parasitaires, Institut de Recherche Biomédicale des Armées, Antenne de Marseille, Institut de Médecine Tropicale du Service de Santé des Armées, Marseille, France and 5Technological Advance for Genomics and Clinics, INSERM U928, parc scientifique de Luminy, Marseille, France

Received: 31 March 2010 Accepted: 25 May 2010

Published: 25 May 2010

\section{References}

1. WHO: The world malaria report 2008. Geneva: World Health Organization; 2008. WHO/HTM/GMP/2008.1.

2. Greenwood BM, Fidock DA, Kyle DE, Kappe SH, Alonso PL, Collins FH, Duffy PE: Malaria: progress, perils, and prospects for eradication. J Clin Invest 2008, 118:1266-1276.

3. Briolant S, Fusai T, Rogier C, Pradines B: Tetracycline antibiotics in malaria. The Open Tropical Medicine Journal 2008, 1:31-46.

4. Shanks GD, Edstein MD, Suriyamongkol V, Timsaad S, Webster HK: Malaria chemoprophylaxis using proguanil/dapsone combinations on the Thai-Cambodian border. Am J Trop Med Hyg 1992, 46:643-648.

5. Ohrt C, Richie TL, Widjaja H, Shanks GD, Fitriadi J, Fryauff DJ, Handschin J, Tang D, Sandjaja B, Tjitra E, et al:: Mefloquine compared with doxycycline for the prophylaxis of malaria in Indonesian soldiers. A randomized, double-blind, placebo-controlled trial. Ann Intern Med 1997, 126:963-972.
6. Andersen SL, Oloo AJ, Gordon DM, Ragama OB, Aleman GM, Berman JD, Tang DB, Dunne MW, Shanks GD: Successful double-blinded, randomized, placebo-controlled field trial of azithromycin and doxycycline as prophylaxis for malaria in western Kenya. Clin Infect Dis 1998, 26:146-150.

7. Gras C, Laroche R, Guelain J, Martet G, Merlin M, Pottier G, Guisset M, Touze JE: Place actuelle de la doxycycline dans la chimioprophylaxie du paludisme à Plasmodium falciparum. Bull Soc Pathol Exot 1993, 86:52-55.

8. Société de Pathologie Infectieuse de Langue Française; Collège des Universitaires de Maladies Infectieuses et Tropicales; Société Française de Médecine des Armées; Société Française de Parasitologie: Société Française de Pédiatrie; Société de Médecine des Voyages; Société de Pathologie Exotique; Société de Réanimation de Langue Française: Recommendations for clinical practice. Management and prevention of imported Plasmodium falciparum malaria. (Revision 2007 of the 1999 Consensus conference). Short text. Med Mal Infect 2008, 38:54-67. 39-53.

9. Briolant S, Baragatti M, Parola P, Simon F, Tall A, Sokhna C, Hovette P, Mamfoumbi MM, Koeck JL, Delmont J, et al:: Multinormal in vitro distribution model suitable for the distribution of Plasmodium falciparum chemosusceptibility to doxycycline. Antimicrob Agents Chemother 2009, 53:688-695.

10. Briolant S, Wurtz N, Zettor A, Rogier C, Pradines B: Susceptibility of Plasmodium falciparum isolates to doxycycline is associated with pftetQ sequence polymorphisms and pftetQ and pfmdt copy numbers. J Infect Dis 2010, 201:153-159.

11. Chopra I, Roberts M: Tetracycline antibiotics: mode of action applications, molecular biology, and epidemiology of bacterial resistance. Microbiol Mol Biol Rev 2001, 65:232-260. second page, table of contents.

12. Pioletti M, Schlunzen F, Harms J, Zarivach R, Gluhmann M, Avila H, Bashan A, Bartels H, Auerbach T, Jacobi C, et al.: Crystal structures of complexes of the small ribosomal subunit with tetracycline, edeine and IF3. Embo J 2001, 20:1829-1839.

13. Blum JJ, Yayon A, Friedman S, Ginsburg H: Effects of mitochondrial protein synthesis inhibitors on the incorporation of isoleucine into Plasmodium falciparum in vitro. J Protozool 1984, 31:475-479.

14. Prapunwattana P, O'Sullivan WJ, Yuthavong Y: Depression of Plasmodium falciparum dihydroorotate dehydrogenase activity in in vitro culture by tetracycline. Mol Biochem Parasitol 1988, 27:119-124

15. Yeo AE, Rieckmann $\mathrm{KH}$, Christopherson Rl: Indirect inhibition by antibiotics of nucleotide and deoxynucleotide biosynthesis in Plasmodium falciparum. Southeast Asian J Trop Med Public Health 1998, 29:24-26.

16. Lin Q, Katakura K, Suzuki M: Inhibition of mitochondrial and plastid activity of Plasmodium falciparum by minocycline. FEBS Lett 2002, 515:71-74.

17. Dahl EL, Shock JL, Shenai BR, Gut J, DeRisi JL, Rosenthal PJ: Tetracyclines specifically target the apicoplast of the malaria parasite Plasmodium falciparum. Antimicrob Agents Chemother 2006, 50:3124-3131.

18. Goodman CD, Su V, McFadden Gl: The effects of anti-bacterials on the malaria parasite Plasmodium falciparum. Mol Biochem Parasitol 2007 152:181-191.

19. List EO, Berryman DE, Bower B, Sackmann-Sala L, Gosney E, Ding J, Okada S, Kopchick JJ: The use of proteomics to study infectious diseases. Infect Disord Drug Targets 2008, 8:31-45.

20. Lasonder E, Ishihama Y, Andersen JS, Vermunt AM, Pain A, Sauerwein RW, Eling WM, Hall N, Waters AP, Stunnenberg HG, et al:: Analysis of the Plasmodium falciparum proteome by high-accuracy mass spectrometry. Nature 2002, 419:537-542.

21. Lasonder E, Janse CJ, van Gemert GJ, Mair GR, Vermunt AM, Douradinha BG, van Noort V, Huynen MA, Luty AJ, Kroeze H, et al.: Proteomic profiling of Plasmodium sporozoite maturation identifies new proteins essential for parasite development and infectivity. PLOS Pathog 2008, 4:e1000195.

22. Radfar A, Diez A, Bautista JM: Chloroquine mediates specific proteome oxidative damage across the erythrocytic cycle of resistant Plasmodium falciparum. Free Radic Biol Med 2008, 44:2034-2042.

23. Koncarevic S, Bogumil R, Becker K: SELDI-TOF-MS analysis of chloroquine resistant and sensitive Plasmodium falciparum strains. Proteomics 2007, 7:711-721 
24. Prieto JH, Koncarevic S, Park SK, Yates J, Becker K: Large-scale differentia proteome analysis in Plasmodium falciparum under drug treatment. PLOS ONE 2008, 3:e4098.

25. Briolant S, Parola P, Fusai T, Madamet-Torrentino M, Baret E, Mosnier J, Delmont JP, Parzy D, Minodier P, Rogier C, et al:: Influence of oxygen on asexual blood cycle and susceptibility of Plasmodium falciparum to chloroquine: requirement of a standardized in vitro assay. Malar J 2007, 6:44.

26. Lambros C, Vanderberg JP: Synchronization of Plasmodium falciparum erythrocytic stages in culture. J Parasitol 1979, 65:418-420.

27. Pradines B, Rogier C, Fusai T, Mosnier J, Daries W, Barret E, Parzy D: In vitro activities of antibiotics against Plasmodium falciparum are inhibited by iron. Antimicrob Agents Chemother 2001, 45:1746-1750.

28. Almeras L, Lefranc D, Drobecq $H$, de Seze J, Dubucquoi S, Vermersch $P$, Prin L: New antigenic candidates in multiple sclerosis: identification by serological proteome analysis. Proteomics 2004, 4:2184-2194.

29. Lin WT, Hung WN, Yian YH, Wu KP, Han CL, Chen YR, Chen YJ, Sung TY, Hsu WL: Multi-Q: a fully automated tool for multiplexed protein quantitation. J Proteome Res 2006, 5:2328-2338.

30. Proteome Center [http://tools.proteomecenter.org/software.php]

31. Martin B, Brenneman R, Becker KG, Gucek M, Cole RN, Maudsley S: iTRAQ analysis of complex proteome alterations in 3xTgAD Alzheimer's mice: understanding the interface between physiology and disease. PLOS ONE 2008, 3:e2750.

32. UniprotKB [http://www.uniprot.org/]

33. PlasmoDB [http://www.plasmodb.org]

34. Foth BJ, Ralph SA, Tonkin CJ, Struck NS, Fraunholz M, Roos DS, Cowman $A F$, McFadden GI: Dissecting apicoplast targeting in the malaria parasite Plasmodium falciparum. Science 2003, 299:705-708.

35. Wurtz N, Desplans J, Parzy D: Phenotypic and transcriptomic analyses of Plasmodium falciparum protein kinase A catalytic subunit inhibition. Parasitol Res 2009, 105:1691-1699.

36. Pradines B, Spiegel A, Rogier C, Tall A, Mosnier J, Fusai T, Trape JF, Parzy D: Antibiotics for prophylaxis of Plasmodium falciparum infections: in vitro activity of doxycycline against Senegalese isolates. Am J Trop Med Hyg 2000, 62:82-85

37. Gritzmacher CA, Reese RT: Protein and nucleic acid synthesis during synchronized growth of Plasmodium falciparum. J Bacteriol 1984, 160:1165-1167.

38. Alvarez S, Berla BM, Sheffield J, Cahoon RE, Jez JM, Hicks LM: Comprehensive analysis of the Brassica juncea root proteome in response to cadmium exposure by complementary proteomic approaches. Proteomics 2009, 9:2419-2431.

39. Wu WW, Wang G, Baek SJ, Shen RF: Comparative study of three proteomic quantitative methods, DIGE, CICAT, and iTRAQ, using 2D gelor LC-MALDI TOF/TOF. J Proteome Res 2006, 5:651-658.

40. Foth BJ, Zhang N, Mok S, Preiser PR, Bozdech Z: Quantitative protein expression profiling reveals extensive post-transcriptional regulation and post-translational modifications in schizont-stage malaria parasites. Genome Biol 2008, 9:R177.

41. Vincensini L, Richert S, Blisnick T, Van Dorsselaer A, Leize-Wagner E, Rabilloud T, Braun Breton C: Proteomic analysis identifies novel proteins of the Maurer's clefts, a secretory compartment delivering Plasmodium falciparum proteins to the surface of its host cell. Mol Cell Proteomics 2005, 4:582-593.

42. Nyalwidhe J, Lingelbach K: Proteases and chaperones are the most abundant proteins in the parasitophorous vacuole of Plasmodium falciparum-infected erythrocytes. Proteomics 2006, 6:1563-1573.

43. Makanga M, Bray PG, Horrocks P, Ward SA: Towards a proteomic definition of CoArtem action in Plasmodium falciparum malaria. Proteomics 2005, 5:1849-1858.

44. Sturm N, Jortzik E, Mailu BM, Koncarevic S, Deponte M, Forchhammer K, Rahlfs S, Becker K: Identification of proteins targeted by the thioredoxin superfamily in Plasmodium falciparum. PLoS Pathog 2009, 5:e1000383.

45. Budimulja AS, Syafruddin, Tapchaisri P, Wilairat P, Marzuki S: The sensitivity of Plasmodium protein synthesis to prokaryotic ribosomal inhibitors. Mol Biochem Parasitol 1997, 84:137-141.

46. Kiatfuengfoo R, Suthiphongchai T, Prapunwattana P, Yuthavong Y: Mitochondria as the site of action of tetracycline on Plasmodium falciparum. Mol Biochem Parasitol 1989, 34:109-115.

47. Ellis KE, Clough B, Saldanha JW, Wilson RJ: Nifs and Sufs in malaria. Mol Microbiol 2001, 41:973-981.
48. Ralph SA, van Dooren GG, Waller RF, Crawford MJ, Fraunholz MJ, Foth BJ, Tonkin CJ, Roos DS, McFadden Gl: Tropical infectious diseases: metabolic maps and functions of the Plasmodium falciparum apicoplast. Nat Rev Microbiol 2004, 2:203-216.

doi: $10.1186 / 1475-2875-9-141$

Cite this article as: Briolant et al., Plasmodium falciparum proteome changes in response to doxycycline treatment Malaria Journal 2010, 9:141

\section{Submit your next manuscript to BioMed Central and take full advantage of:}

- Convenient online submission

- Thorough peer review

- No space constraints or color figure charges

- Immediate publication on acceptance

- Inclusion in PubMed, CAS, Scopus and Google Scholar

- Research which is freely available for redistribution

Submit your manuscript at www.biomedcentral.com/submit
C) Biomed Central 